\title{
LASIK excimer misfire on fluence test mode: induced refractive error quantification and corneal ablation profile
}

\author{
Sudarshan Khokhar, Amber Amar Bhayana ำ, Priyanka Prasad, Avilasha Mohapatra
}

Dr Rajendra Prasad Centre for Ophthalmic Sciences, All India Institute of Medical Sciences, New Delhi, India

\section{Correspondence to} Dr Amber Amar Bhayana; amber.amar.bhayana@gmail. com

Accepted 17 June 2021

\section{DESCRIPTION}

A 23-year-old man with refractive error as in figure 1A was planned for LASIK (Laser assisted in-situ keratomileusis) refractive surgery (ZEISS MEL 90). After flap preparation, the subject was accidentally fired on by excimer laser at fluence test settings ${ }^{1}$ instead of that for the individualised refractive error in the right eye. The fluence was kept at 0 . The flap was repositioned and any other intervention in this or the other eye was withheld for the time being. A sample fluence test ablation profile on fluence paper has been shown (figure 1B). The ablation has been shown in online supplemental file 1.

Preoperative corneal thickness map (figure 2A) was compared with the 6 weeks postsurgery map (figure 2B) and inference was drawn that majority of the ablation was seen in superior half of the cornea and peripheral more than central cornea was ablated. Ablation amounts were 18 and 13 microns superiorly; 7 and 6 microns inferiorly in $90^{\circ}$ meridian at outer third and second measurement circles on pachymetry map. This corroborates with the ablation pattern seen on sample fluence paper (figure 1B) where superior half of the circle changes colour from silver to green showing the excimer firing pattern. The refractive error of the patient changed and stabilised to -4.75 dioptres sphere with -1 dioptres cylinder at $20^{\circ}$. The amount of refractive error induced was about 0.25 dioptres myopia. The patient was replanned for surgery. The same older flap was re-lifted and the new refractive error was corrected (normal LASIK for the other

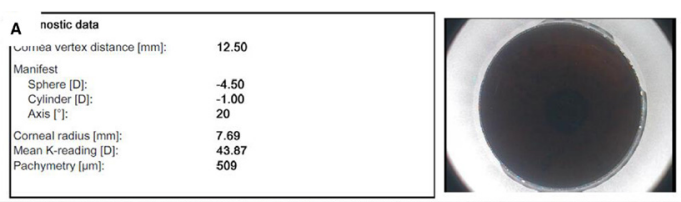

(c) BMJ Publishing Group Limited 2021. No commercial re-use. See rights and permissions. Published by BMJ.

To cite: Khokhar $S$ Bhayana AA, Prasad P, et al. BMJ Case Rep

2021;14:e244397.

doi:10.1136/bcr-2021

244397

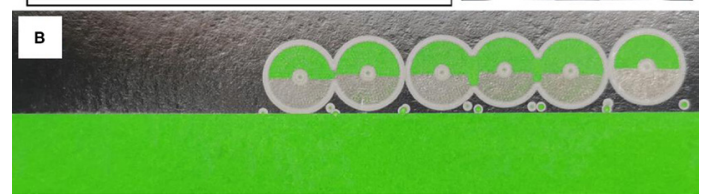

Figure 1 (A) Refractive error details of the patient's right eye, (B) fluence paper showing ablation pattern of a normal excimer fluence test: the colour change from silver to green determines the excimer firing pattern.

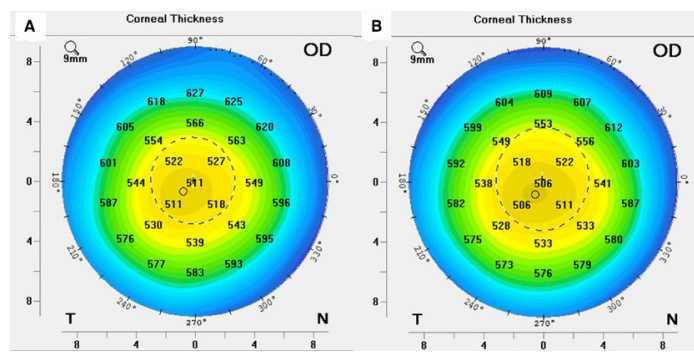

Figure 2 (A) Preoperative pachymetry map; (B) postoperative pachymetry map.

\section{Learning points}

Fluence excimer causes peripheral more than central, and superior more than inferior.

- After any error in excimer firing, 6 weeks time should be given to allow the cornea to heal, then the same flap can be lifted and the bed ablated according to the new refractive error.

- To prevent such incidences, always look up at the screen before firing and keep an assistant who announces when to fire as you are busy with patient centring and keep them calm and relaxed; also the machine screen always displays subject's refractive error before and while refractive correction excimer firing (not seen during excimer fluence testing).

eye) with postoperative uncorrected visual acuity of each eye being 20/20.

We would thus like to report that a fluence test excimer firing (fluence at 0) (ZEISS MEL 90) ablates superior more than inferior and peripheral more than central cornea, mean of about 13 microns superiorly and 6 microns inferiorly (measured at outer second pachymetry map circle); and amount of refractive error induced is 0.25 dioptres myopia on account of periphery ablated more than the centre.

Contributors SK contributed to surgery, concept, editing. $A A B$ contributed to concept, preparation of manuscript. PP contributed to editing. AM contributed to data retreival.

Funding The authors have not declared a specific grant for this research from any funding agency in the public, commercial or not-for-profit sectors.

Competing interests None declared.

Patient consent for publication Obtained. 
Images in...

Provenance and peer review Not commissioned; externally peer reviewed.

\section{REFERENCE}

ORCID ID

1 Dantas PEC, Martins $C L$, de Souza $L B$, et al. Do environmental factors influence excimer laser pulse fluence and efficacy? J Refract Surg 2007;23:307-9.

Amber Amar Bhayana http://orcid.org/0000-0002-0770-601X

Copyright 2021 BMJ Publishing Group. All rights reserved. For permission to reuse any of this content visit https://www.bmj.com/company/products-services/rights-and-licensing/permissions/

BMJ Case Report Fellows may re-use this article for personal use and teaching without any further permission.

Become a Fellow of BMJ Case Reports today and you can:

- Submit as many cases as you like

- Enjoy fast sympathetic peer review and rapid publication of accepted articles

Access all the published articles

Re-use any of the published material for personal use and teaching without further permission

Customer Service

If you have any further queries about your subscription, please contact our customer services team on +44 (0) 2071111105 or via email at support@bmj.com.

Visit casereports.bmj.com for more articles like this and to become a Fellow 